\title{
The cariostatic mechanisms of fluoride
}

\author{
Kata Rošin-Grget, Kristina Peroš, Ivana Šutej, Krešimir Bašić
}

Department of Pharmacology, School of Dental Medicine, University of Zagreb Zagreb, Croatia

\author{
Corresponding author: \\ Kata Rošin-Grget \\ Department of Pharmacology \\ School of Dental Medicine \\ Šalata 11 \\ 10000 Zagreb \\ Croatia \\ rosin@sfzg.hr \\ Tel.: + 38514566957 \\ Fax.: + 38514920049
}

Received: 27 March 2013

Accepted: 8 May 2013

Copyright (C) 2013 by

Academy of Sciences and Arts

of Bosnia and Herzegovina.

E-mail for permission to publish:

amabih@anubih.ba

\begin{abstract}
This article discusses the possible cariostatic mechanisms of the action of fluoride. In the past, fluoride inhibition of caries was ascribed to reduced solubility of enamel due to incorporation of fluoride $\left(\mathrm{F}^{-}\right)$into the enamel minerals. The present evidence from clinical and laboratory studies suggests that the caries-preventive mode of action of fluoride is mainly topical. There is convincing evidence that fluoride has a major effect on demineralisation and remineralisation of dental hard tissue. The source of this fluoride could either be fluorapatite (formed due to the incorporation of fluoride into enamel) or calcium fluoride $\left(\mathrm{CaF}_{2}\right)$-like precipitates, which are formed on the enamel and in the plaque after application of topical fluoride. Calcium fluoride deposits are protected from rapid dissolution by a phosphate -protein coating of salivary origin. At lower $\mathrm{pH}$, the coating is lost and an increased dissolution rate of calcium fluoride occurs. The $\mathrm{CaF}_{2}$, therefore, act as an efficient source of free fluoride ions during the cariogenic challenge. The current evidence indicates that fluoride has a direct and indirect effect on bacterial cells, although the in vivo implications of this are still not clear. Conclusion. A better understanding of the mechanisms of the action of fluoride is very important for caries prevention and control. The effectiveness of fluoride as a cariostatic agent depends on the availability of free fluoride in plaque during cariogenic challenge, i.e. during acid production. Thus, a constant supply of low levels of fluoride in biofilm/saliva/dental interference is considered the most beneficial in preventing dental caries.
\end{abstract}

Key words: Dental caries, Fluorides, Tooth remineralization.

\section{Introduction}

The use of fluoride in dentistry is one of the most successful preventive health measures in the history of dental care. However, the mechanism of fluoride action is still not clearly understood. The cariostatic effect of fluoride was first discovered in relation to the natural fluoride content of drinking water. Later, supplementation of public water supplies with controlled levels of fluoride was the first approach, involving the use of fluoride for caries control. In the middle of the previous century, it was generally believed that fluoride had to be incorporated into dental enamel during development. This would lead to the formation of enamel with reduced solubility. This is usually referred to as the systemic cariostatic effect of fluoride (1). Many clinical trials were designed to prove the systemic mode of action (2-4). Additionally, laboratory analyses revealed that fluoride concentration in surface 
enamel was higher in teeth that developed under the influence of water fluoridation (5). A hypothesis evolved which suggested that fluoride helped to make the enamel crystal "more perfect", and therefore less acid soluble. Le Geros et al. (6) performed a physicochemical investigation of enamel from deciduous teeth. They found that enamel from children who had been subjected to prenatal fluoridation exhibited more homogeneous and less extensive patterns of acidetching, denser crystal populations in intraprismatic regions, larger prism dimensions, greater total mineral density, a higher degree of crystallinity, smaller a-axis dimensions, more fluoride and less carbonate contents. However, in vitro studies revealed that the reduction in enamel solubility by pre-eruptive incorporation of fluoride is minor and therefore it is unlikely that the fluoride incorporated into enamel plays an important role in the observed caries reduction $(7,8)$. Also, in some studies no significant correlation could be established between dental caries experience and enamel fluoride concentration $(9,10)$.

The topical effect of fluoride was demonstrated by Bibby et al. (11), who compared the caries-preventing efficacy of fluoride lozenges, intended to be sucked, with coated fluoride pills intended to be swallowed in a group of 5 to 14 -year-old children. In the group using lozenges fewer carious lesions developed compared to the group using pills. They concluded that the caries reduction was the result of fluoride acting on the external surface of the teeth, because the lozenges were in contact with teeth much more than pills which were swallowed. This study provided clear evidence that the mechanism of the action of fluoride is mostly post-eruptive. Later, topical fluoride agents were introduced to provide fluoride to individuals in non-fluoridated areas. In a large number of studies, topical fluorides have been shown to be effective in caries prevention (12). In the 1980s, the concept was established that fluoride controls caries lesion development, primarily through its topical effect on deand remineralisation processes taking place at the interface between the tooth surface and the oral fluids $(13,14)$. This concept was established after very elegant in situ studies described by Øgaard et al. (15). They placed human and shark enamel (composed almost of pure fluorapatite) in a removable appliance and covered them with orthodontic bands to allow plaque accumulation. $\mathrm{Mi}$ croradiographic analyses revealed that carious lesions were formed in both substrates. However, fluoride supplementation, in the form of mouth rinses, inhibited lesion development. This observation has indicated that structurally bound fluoride is not very effective in inhibiting demineralisation, while fluoride in solution ( $\mathrm{NaF}$ solution) leads to a high degree of protection. Furthermore, a randomized, double blind, longitudinal study, testing the caries - preventing efficacy of prenatal fluoride supplementation in children up to age 5, failed to support the hypothesis that prenatal fluoride has a strong caries preventive effect (16). When fluoride was first introduced in caries prevention, water fluoridation was followed by a decline in caries, while interruptions in fluoridation were followed by increasing caries levels. However, the latest decades have shown a significant caries decrease despite the fact that there was poor water fluoridation (17, 18). The authors proposed that one of the reasons might be the availability of other fluoride-containing products, e.g. fluoride dentifrices.

The results of more recent epidemiological and laboratory studies can be summarized by stating that post-eruptive (topical) application of fluoride plays the dominant role in caries prevention (1). However, this concept does not invalidate the "systemic" methods of fluoridation. The recent studies have shown a beneficial pre-eruptive effect 
of water fluoride on caries control. The use of fluoridated water until eruption only has a greater effect than the use only between eruption and age 15 in all categories of surfaces on the first molar, especially in pit and fissure surfaces $(19,20)$.

The present article discusses the current concept of the mechanisms of the fluoride cariostatic effect, an understanding of which is necessary for promotion of caries control.

\section{The composition of enamel and dentine}

The dental hard tissue consists of inorganic and organic materials in different quantities. Highly calcified enamel has approximately $85 \%$ mineral by volume, organic material $3 \%$ and $12 \%$ water by volume (1). Histologically, enamel is composed of so called prisms or rods, each being composed of clusters of small crystallites. The spaces between the prisms and the crystallites are filled with water and organic material (protein and lipids), and form the diffusion pathways for acids, mineral components, and fluoride ions (21). The solid phase of enamel consists mainly of crystallized calcium phosphate, which persists in different forms (mainly as hydroxyapatite and some less stable forms such as dicalcium phosphate dihydrate (DCPD), brushite or octacalcium phosphate (OCP). The mineral component of human dental enamel is basically a calcium-deficit carbonate hydroxyapatite. Carbonated calcium hydroxyapatite is more soluble than calcium hydroxyapatite, particularly in acidic media $(14,22,23)$. The pure hydroxyapatite $\left[\mathrm{Ca}_{10}\left(\mathrm{PO}_{4}\right)_{6}(\mathrm{OH})_{2}\right]$ allows the incorporation of many ions that fit into the crystallite structure and affect its solubility. The substitution in the hydroxyapatite crystal occurs during development with carbonate, magnesium, fluoride, etc. Fluoride improves the quality of mineralized tooth tissues in general, by reducing the relative amounts of carbonated apatite. The reaction between hydroxyapa- tite and low concentrations of fluoride has been postulated to be an ionic exchange, in which fluoride replaces and assumes the positions of the hydroxyl ions in the crystal lattice structure. The replacement of hydroxyl groups with the smaller fluoride ions should result in a more stable apatitic structure. If the $\mathrm{OH}^{-}$ion in the pure hydroxyapatite is completely replaced by a fluoride ion $\left(\mathrm{F}^{-}\right)$the resulting mineral is fluorapatite $\left[\mathrm{Ca}_{10}\left(\mathrm{PO}_{4}\right)_{6} \mathrm{~F}_{2}\right]$. However, pure fluorapatite can practically never be found. Only $10 \%$ of the hydroxyl groups can be substituted by fluoride in the surface enamel (24).

The main mineral phase of permanent dentin is also hydroxyapatite. Dentine contains (by volume) $47 \%$ apatite, $33 \%$ organic components and $20 \%$ water. The crystallites have much smaller dimensions than those found in enamel, which makes dentine more susceptible to caries attack than enamel. Smaller crystallites dissolve faster when placed in an under-saturated solution. The organic matrix is mainly composed of collagen. It forms the backbone of dentine and serves as a template for the deposition of apatite crystallites within the collagen helix. Dental caries is a biochemical process characterized initially by the dissolution of the mineral, which in turn exposes the organic matrix to breakdown by bacterial-derived enzymes, as well as by the host derived enzymes (e.g. metalloproteinase) present in dentine and saliva $(1,25)$.

\section{Caries development}

Over 100 years ago, dental caries was described as localized, progressive destruction of the tooth initiated by acid dissolution of the outer tooth surface. In the presence of fermentable carbohydrates, organic acids are produced by plaque microorganisms, which colonize the tooth surface. The acids (i.e. lactic, pyruvic, acetic, propionic, butyric) can dissolve the calcium phosphate 
mineral of the enamel or dentine (demineralisation) (26). This concept evolved as the foundation for our current knowledge of caries aetiology. Dental caries is the net result of consecutive cycles of de- and remineralisation of dental tissues at the interface between the biofilm (plaque) and the tooth surface, with demineralisation being caused by production of acids through oral bacteria after sugar consumption. The acids diffuse through the plaque into the pores of the sound enamel surface, releasing hydrogen ions, which can dissolve the underlying enamel. The dissolved mineral ions, calcium and phosphate will then back-diffuse into the surface layer and induce the precipitation of the mineral phases in this region. At the same time, some of the dissolved mineral ions will diffuse out of the enamel surface into the oral environment. It is known that incipient or small carious lesions ("white spot lesions") in human enamel consist of a subsurface area of demineralisation with an overlying, apparently intact, surface zone. It is considered that the enamel surface layer is a result of reprecipitation of minerals (remineralisation) dissolved from the subsurface. The leaching of calcium and phosphate from enamel can cause collapse of the tooth structure and the formation of a cavity. Demineralisation and remineralisation can be considered a dynamic process, characterized by the flow of calcium and phosphate out of and back into the enamel (27).

The saliva plays an important role, including buffering (neutralizing) the acid and providing minerals that replace those dissolved from the tooth during demineralisation challenge. The enamel surface is in constant contact with saliva, which is considered to be saturated with certain calcium phosphate salts, thereby maintaining the integrity of the enamel surface. It was found that, within physiological $\mathrm{pH}$ limits, the salivary content of calcium and inorganic phosphate was sufficient to supersaturate the saliva with respect to hydroxyapatite. The protective factors, which include salivary calcium, phosphate and proteins, salivary flow, and fluoride in saliva, can balance, prevent or reverse dental caries (26).

When a biofilm covers the enamel surface, it reduces the access of saliva to the tooth. The relevant fluid phase in this case is the biofilm fluid, which, under resting conditions, is also supersaturated with respect to the enamel. This would favour remineralisation of previously demineralized enamel or promote the formation of supragingival calculus (1). However, when the oral fluids become unsaturated with respect to the apatites e.g., caused by a $\mathrm{pH}$ drop, a change in apatite composition may occur. In the $\mathrm{pH}$ range below about 5.5, the oral fluids are unsaturated with respect to hydroxyapatite, which therefore may dissolve. The low fluoride concentrations prevailing in oral fluids under physiological conditions will ensure a concurrent supersaturation with respect to fluorapatite, theoretically in the $\mathrm{pH}$ range of about 5.5 - 4.5, so that dissolution of hydroxyapatite competes with simultaneous fluorapatite or mixed fluorohydroxyapatite formation. Consequently, hydroxyapatite dissolves from the subsurface and fluorohydroxyapatite forms in the surface layers (28).

\section{Inhibition of demineralisation}

The highest fluoride concentrations in enamel are found in the surface. They are usually around 1,000-2,000 ppm in nonfluoridated areas and 3,000 in fluoridated areas. Subsurface enamel generally contains fluoride at levels of about 20-100 ppm, depending on fluoride ingestion during tooth development. These levels are far below those able to confer expressive reduction on the solubility of hydroxyapatite (26). Based on solubility data, the thermodynamic solubility product constant (Ksp) of fluorapatite is only slightly less than that of 
hydroxyapatite (28). Concentrations of fluoride found in shark enamel are many times higher than those typically found in human enamel, but even so they were unable to inhibit demineralisation completely (15). On the other hand, it has been observed that low concentrations (up to $1 \mathrm{ppm}$ ) of fluoride in a solution can reduce and even inhibit enamel demineralisation (24). It was shown that inhibition of demineralisation is a logarithmic function of the fluoride concentration in a solution (14). These results indicated that if fluoride is present in the solution surrounding the crystals (enamel fluid) it is adsorbed strongly to the surface of carbonated apatite crystals acting as a potent protection mechanism against acid dissolution of the crystal surface. When the entire crystal surface is covered by adsorbed fluoride $\left(\mathrm{F}_{\mathrm{A}}\right)$, it will not dissolve upon a $\mathrm{pH}$ fall caused by bacterial-derived acids. Crommelin et al. (29) observed that fluorapatitecoated hydroxyapatite dissolved largely the same as fluorapatite, although the hydroxyapatite in a hydroxyapatite and fluorapatite mixture dissolved the same as hydroxyapatite. Therefore, significant protection could be obtained if all crystals along the acid ions diffusion pathway are coated with fluorapatite. On the other hand, when the coating of $\mathrm{F}_{\mathrm{A}}$ is partial, the uncoated parts of the crystal will undergo dissolution (30). Ten Cate and Duijsters (31) showed that the amount of mineral loss during demineralisation is a function of both $\mathrm{pH}$ and fluoride concentration. When the fluoride concentration in the solution is elevated the fluorapatite is correspondingly increased and it appears sufficient to prevent a caries lesion from developing. While fluoride adsorbed to the crystal surface effectively protects the crystal from dissolution, fluoride present in the solution (enamel fluid) is equally important, since the higher the concentration of fluoride in enamel fluid $\left(\mathrm{F}_{\mathrm{L}}\right)$, the higher the probability that it adsorbs and protects crys- tal (1). Thus, to interfere in the dynamics of dental caries formation, fluoride must be constantly present in the oral environment. Demineralisation of enamel is inhibited by concentrations of fluoride in the sub-ppm range (21). Frequent low-level applications of fluoride are more effective than high-dose applications a few times a year, because $F_{L}$ and thus $\mathrm{F}_{\mathrm{A}}$ are maintained high with frequent applications (30).

\section{Enhancement of remineralisation}

The acids produced by the plaque bacteria diffuse through the plaque into the enamel and dissolve minerals (calcium, phosphate and fluoride) wherever there is a susceptible site. If minerals diffuse out of the tooth and into the oral environment, then demineralisation occurs. If this process is reversed, the mineral is reabsorbed into the tooth and the damaged crystals are rebuilt, we then have remineralisation. The role of fluoride in the remineralisation process was found to be rather complex. Fluoride acts by inhibiting mineral loss at the crystal surface and by enhancing this rebuilding or remineralisation of calcium and phosphate in a form more resistant to subsequent acid attack (32). Over 30 years ago Brown et al. (33) predicted that low concentrations of fluoride would enhance remineralisation. Traces of fluoride in a solution during dissolution of hydroxyapatite will make the solution highly supersaturated with respect to fluorohydroxyapatite. This will speed up the process of remineralisation. Fluoride will adsorb to the surface of partially demineralized crystals and attract calcium ions. Koulourides (34) demonstrated that acid-softened enamel, rehardened by fluoridation, acquired significant secondary resistance to acid attack, developing so-called "acquired resistance". The acquired fluoride enhances both remineralisation and demineralisation resistance. 


\section{Role of fluorapatite and calcium fluoride}

There are three principle forms of fluoride ion reactivity with apatite:

1) Iso-ionic exchange of $\mathrm{F}^{-}$for $\mathrm{OH}^{-}$in apatite:

$$
\begin{aligned}
& \mathrm{Ca}_{10}\left(\mathrm{PO}_{4}\right)_{6}(\mathrm{OH})_{2}+2 \mathrm{~F}^{-} \rightarrow \mathrm{Ca}_{10}\left(\mathrm{PO}_{4}\right)_{6} \mathrm{~F}_{2}+ \\
& 2 \mathrm{OH}^{-}
\end{aligned}
$$

2) Crystal growth of fluorapatite from supersaturated solutions:

$$
10 \mathrm{Ca}^{2+}+6 \mathrm{PO}_{4}^{3-}+2 \mathrm{~F}^{-} \rightarrow \mathrm{Ca}_{10}\left(\mathrm{PO}_{4}\right)_{6} \mathrm{~F}_{2}
$$

3) Apatite dissolution with $\mathrm{CaF}_{2}$ formation: $\mathrm{Ca}_{10}\left(\mathrm{PO}_{4}\right)_{6}(\mathrm{OH})_{2}+20 \mathrm{~F}^{-} \rightarrow 10 \mathrm{CaF}_{2}+$ $6 \mathrm{PO}_{4}^{3-}+2 \mathrm{OH}$

The first two reactions may occur during long-term exposure to low fluoride levels in the solution (such as between 0.01 and $10 \mathrm{ppm} \mathrm{F}$ ) from either systemic or latent topical sources. These reactions result in fluoride incorporation that, in a traditional sense, would be defined as "firmly" bound fluoride, since it is part of the apatitic structure. This fluoride present in the solid phase is also known as fluorohydroxyapatite or "systemic" fluoride. With the increasing fluoride concentration, an additional chemical reaction with the formation of significant amounts of calcium fluoride $\left(\mathrm{CaF}_{2}\right.$ or " $\mathrm{CaF}_{2}$ like" material) begins to dominate. Fluoride concentrations ranging from 100-10,000 ppm $\mathrm{F}$ are required to produce $\mathrm{CaF}_{2}$ as a reaction product (often called $\mathrm{F}_{\text {on }}$ ) These concentrations are present in topicals, such as professional gels and varnishes, or over the counter toothpastes and mouth rinses (35).

As early as in 1945, Gerould (36) reported that calcium fluoride was a major product on enamel when teeth were exposed to high concentrations of fluoride. It is visible by scanning with an electron microscope (SEM) as small globules on the surface of fluoridated teeth. The globular precipitates on the enamel are more homogeneous when the fluoride concentration of the applied solution is higher (37). The globular structure of the calcium fluoride is thought to be due to the incorporation of phosphate during its formation on the tooth surface (38), since pure calcium fluoride is cubical rather than spherical. For a long period the general view was that the formation of calcium fluoride on enamel is unfavourable, because calcium fluoride is soluble in saliva to the same extent as in water (39). The oral fluids are unsaturated with respect to calcium fluoride, thus this salt dissolves whenever it is exposed to saliva (40). However, several studies have shown that calcium fluoride is quite insoluble in saliva at neutral $\mathrm{pH}$, and that it can persist on the tooth surface for weeks and months after topical application of fluoride (41-43). The resistance of calcium fluoride is presumably caused by adsorption of secondary phosphate $\left(\mathrm{HPO}_{4}{ }^{2-}\right)$ to calcium sites in the surface of calcium fluoride crystals and by pellicle proteins at neutral $\mathrm{pH}$. At lower $\mathrm{pH}$, as during a caries attack, primary phosphate will be the dominant phosphate ion species $\left(\mathrm{H}_{2} \mathrm{PO}_{4}^{-}\right)$, which is unable to inhibit the dissolution of calcium fluoride. Thus, fluoride ions released during cariogenic challenges are due to the reduced concentration of secondary phosphate ions at acid $\mathrm{pH}$. The released fluoride is subsequently built into hydroxyapatite through dissolution/reprecipitation reactions. After a caries attack, the calcium fluoride globules are again stabilized by adsorption of proteins and secondary phosphate (44). Calcium fluoride thus constitutes a $\mathrm{pH}$-controlled reservoir of fluoride on the enamel. Calcium fluoride is contaminated with phosphate, not only on the surface, but also inside the crystal. This phosphate-contaminated calcium fluoride is more soluble than pure calcium fluoride, and may thus release fluoride at a higher rate than pure calcium fluoride (38). $\mathrm{CaF}_{2}$ formed at low $\mathrm{pH}$ contains less internal phosphate, and has been shown to be less soluble. This may be of clinical significance for fluoride applied topically a few times per year (41). The calcium fluo- 
ride formation, its resistance in the oral environment and release of fluoride ions at low $\mathrm{pH}$, explain the long-term effect of topically applied fluoride. It is suggested that the potential for formation of calcium fluoride should probably be increased in topical fluoride agents (45). Increased time of exposure, increased concentration, lowered $\mathrm{pH}$, saliva and calcium pre-treatment have proved to be effective means of increasing calcium fluoride deposition on enamel in vitro (46-49).

\section{The antimicrobial action of fluoride}

In spite of extensive literature on the antimicrobial effects of fluoride on oral microflora, today there is very little consensus that the anticaries effect of fluoride is related to inhibition of oral bacteria.

The current evidence indicates that fluoride has a multitude of direct and indirect effects on bacterial cells, some of which may have a significant influence on the acid -producing microorganisms in dental plaque (50). Fluoride exerts its effect on oral bacteria by direct inhibition of cellular enzymes (directly or in combination with metals) or enhancing the proton permeability of cell membranes in the form of hydrogen fluoride (HF) $(51,52)$.

In order to provoke any antimicrobial effect, fluoride has to enter the bacterial cell. Fluoride diffuses into cariogenic bacteria in the form of HF (a weak acid, pKa 3.15). At lower external $\mathrm{pH}$, more $\mathrm{HF}$ is formed and more of it diffuses into the cell. Once inside the cell, the $\mathrm{HF}$ dissociates into $\mathrm{H}^{+}$and $\mathrm{F}^{-}$, because of the higher internal $\mathrm{pH}$ of cells, such as oral streptococci, than external. This continued diffusion and dissociation leads to the accumulation of fluoride in the cell and the acidification (accumulation of $\mathrm{H}^{+}$) of the cytoplasm. The result is a reduction in both the proton gradient and the enzyme activity. Current information indicates that fluoride ions within the cell interfere with the glycolitic enzyme (enolase) activity and proton-extruding adenosine triphosphatase $\left(\mathrm{H}^{+} /\right.$ATP-ase $)$, which is involved in the generation of proton gradients through the efflux of protons from the cell, at the expense of ATP (53).Thus, fluoride effectively inhibits the carbohydrate metabolism of acidogenic oral bacteria, including the uptake of sugars. In spite of these known effects, there is no general agreement that the antimicrobial effects of $\mathrm{F}$ contribute to the anticaries effect of fluoride $(53,54)$.

Many investigators tend to dismiss the role of fluoride in the metabolic activity of bacteria, on the grounds that only large concentrations are effective, and that there are no differences in the Streptococcus mutans populations in persons residing in fluoridated and in non-fluoridated areas (55). In addition, the widespread use of toothpastes, which have been responsible for the decrease in caries prevalence over the last three decades, has not resulted in a reduction in the number of the mutans streptococci (56). Lynch et al. (57) concluded that low levels of plaque and salivary fluoride, resulting from the use of $1,500 \mathrm{ppm}$ fluoride toothpastes, are insufficient to have a significant antimicrobial effect on plaque bacteria. It seems that this effect is dependent on factors such as fluoride concentration and associated antibacterial components, such as fluoride counter ions (amine, stannous), preservatives, surfactants or antimicrobials added specifically for that purpose (zinc salts, triclosan, essential oil extracts, etc.) (58). A single application of professionally applied topical fluoride at a high concentration, although transient, reduces the plaque's ability to produce acid, but has little clinical significance in controlling dental caries.

A recent review, however, concluded that fluoride concentrations, as found in dental plaque, have a biological action on critical virulence factors of $S$. mutans in vitro, such as acid production and glucan synthesis, but the in vivo implications are still not clear (51). 


\section{Conclusion}

Understanding the mode of action of fluoride has an essential role in the further development of products and programmes for caries prevention. In the past, the cariostatic effect of fluoride was attributed to the incorporation of fluoride in the hydroxyapatite crystal lattice and the reduced solubility of the so-formed fluoridated hydroxyapatite. Recent findings have altered this view. The current evidence from clinical and laboratory studies suggests that the caries-preventive mode of action of fluoride is mainly topical. Specifically, fluoride continually present in the oral fluids affects the demineralisation and remineralisation processes. Fluoride present in the solution surrounding the crystals (enamel fluid) in a sub-ppm range is able to adsorb to the surface of the carbonated apatite crystals, inhibiting demineralisation. However, in the clinical situation, the optimum fluoride level to prevent caries development is not known. When fluoride ions are present during remineralisation, they become incorporated in the apatite structure, forming fluor-hydroxyapatite mixed crystals, which are more resistant to future acid challenges. The formation of intraoral reservoirs capable of supplying ions for a prolonged period is crucial for the success of topical treatments. Fluoride, which is retained on the teeth after brief exposure to topical fluoride agents or toothpastes, is retained as calcium fluoride. Calcium fluoride is most likely the provider of free ions during cariogenic challenges. Calcium fluoride globules are protected from rapid dissolution by a phosphate -protein coating of salivary origin, which will open at low $\mathrm{pH}$, when, incidentally, the fluoride is most needed. The fluoride present inside the solid enamel is most likely of lesser importance than fluoride in solution. In fact, this fluoride is not effective until exposed, due to crystallite dissolution. Upon post-eruption acidic challenge, "firmly" bound fluoride would be released to the fluid phase, thus inhibiting demineralisation and enhancing remineralisation. Evidence from cohort studies also supports fluoride's systemic mechanism of caries inhibition, especially in the pit and fissure surfaces of permanent first molars. Some of the efficacy of fluoride is attributed to the effect on the plaque volume and metabolic aspects of the plaque bacteria, although the in vivo implications of this are still not clear.

Authors' contributions: Conception and design: KRG, KP, IŠ; Acquisition, analysis and interpretation of data: KRG, KP, KB; Drafting the article: KRG, KP, IŚ; Revising it critically for important intellectual content: KRG, KP, KB.

Conflict of interest: The authors declare that they have no conflict of interest.

\section{References}

1. Buzalaf MA, Pessan JP, Honório HM, ten Cate JM. Mechanisms of action of fluoride for caries control. Monogr Oral Sci. 2011;22:97-114.

2. Backer Dirks O, Künzel W, Carlos JP. Caries preventive water fluoridation. Caries Res. 1978;12(Suppl 1):7-14.

3. Thylstrup A, Bille J, Bruun C. Caries prevalence in Danish children living in areas with low and optimal levels of natural water fluoride. Caries Res. 1982;16(5):413-20.

4. Newbrun E. Effectiveness of water fluoridation. J Public Health Dent. 1989;49(5 Spec No):279-89.

5. Chan JT, Qiu CC, Whitford GM, Weatherred JG, Clardy RK. The distribution of fluoride of prenatal origin in the rat: a pilot study. Arch Oral Biol. 1989;34(11):885-8.

6. LeGeros RZ, Glenn FB, Lee DD, Glenn WD. Some physico-chemical properties of deciduous enamel of children with and without prenatal fluoride supplementation (PNF). J Dent Res. 1985;64(3):465-9.

7. Larsen MJ. Dissolution of enamel. Scand J Dent Res. 1973;81(7):518-22.

8. Fejerskov O, Thylstrup A, Larsen MJ. Rational use of fluorides in caries prevention. A concept based on possible cariostatic mechanisms. Acta Odontol Scand. 1981;39(4):241-9. 
9. Nasir HI, Retief DH, Jamison HC. Relationship between enamel fluoride concentration and dental caries in a selected population. Community Dent Oral Epidemiol. 1985;13(2):65-7.

10. Retief DH, Harris BE, Bradley EL. Relationship between enamel fluoride concentration and dental caries experience. Caries Res. 1987;21(1):68-78.

11. Bibby BG, Wilkins E, Witol E. A preliminary study of the effects of fluoride lozenges and pills on dental caries. Oral Surg Oral Med Oral Pathol. 1955;8(2):213-6.

12. Pessan JP, Toumba KJ, Buzalaf MA. Topical use of fluorides for caries control. Monogr Oral Sci. 2011;22:115-32.

13. Ten Cate JM. In vitro studies on the effects of fluoride on de- and remineralisation. J Dent Res. 1990;69 Spec No:614-9; discussion 634-6.

14. Featherstone JD, Glena R, Shariati M, Shields CP. Dependence of in vitro demineralisation of apatite and remineralisation of dental enamel on fluoride concentration. J Dent Res. 1990;69 Spec No:620-5; discussion 634-6.

15. Øgaard B, Rölla G, Dijkman T, Ruben J, Arends J. Effect of fluoride mouthrinsing on caries lesion development in shark enamel: an in situ caries model study. Scand J Dent Res. 1991;99(5):372-7.

16. Leverett DH, Adair SM, Vaughan BW, Proskin HM, Moss ME. Randomized clinical trial of the effect of prenatal fluoride supplements in preventing dental caries. Caries Res. 1997;31(3):174-9.

17. Künzel W, Fischer T. Rise and fall of caries prevalence in German towns with different $\mathrm{F}$ concentrations in drinking water. Caries Res. 1997;31(3):166-73.

18. König KG. Reasons for increasing the fluoride content of children's toothpastes. Oralprophylaxe. 2001;23:27-31.

19. Groeneveld A, Van Eck AA, Backer Dirks O. Fluoride in caries prevention: is the effect pre- or post-eruptive? J Dent Res. 1990;69 Spec No:751-5; discussion 820-3.

20. Singh KA, Spencer AJ. Relative effects of pre- and post-eruption water fluoride on caries experience by surface type of permanent first molars. Community Dent Oral Epidemiol. 2004;32(6):435-46.

21. ten Cate JM, Featherstone JDB. Mechanistic aspects of the interactions between fluoride and dental enamel. Crit Rev Oral Biol Med. 1991;2(3):283-96.

22. LeGeros RZ, Tung MS. Chemical stability of carbonate- and fluoride-containing apatites. Caries Res. 1983;17(5):419-29.

23. Kautsky MB, Featherstone JD. Effect of salivary components on dissolution rates of carbonated apatites. Caries Res. 1993;27(5):373-7.
24. Margolis HC, Moreno EC. Physicochemical perspectives on the cariostatic mechanisms of systemic and topical fluorides. J Dent Res. 1990;69 Spec No:606-13; discussion 634-6.

25. Chaussain-Miller C, Fioretti F, Goldberg M, Menashi S. The role of matrix metalloproteinases (MMPs) in human caries. J Dent Res. 2006;85(1):22-32.

26. Featherstone JD. Prevention and reversal of dental caries: role of low level fluoride. Community Dent Oral Epidemiol. 1999;27(1):31-40.

27. Fejerskov O, Kidd EA, Nyvad B, Baelum V. Defining the disease: an introduction. In: Fejerskov $\mathrm{O}$, Kidd E, editors. Dental caries. The disease and its clinical managment. 2nd ed. Oxford: BlackwellMunksgaard; 2008. p. 3-6.

28. ten Cate JM. Review on fluoride, with special emphasis on calcium fluoride mechanisms in caries prevention. Eur J Oral Sci. 1997;105(5 Pt 2):461-5.

29. Crommelin DJ, Higuchi WI, Fox JL, Spooner PJ, Katdare AV. Dissolution rate behavior of hydroxyapatite-fluorapatite mixtures. Caries Res. 1983;17(4):289-96.

30. Arends J, Christoffersen J. Nature and role of loosely bound fluoride in dental caries. J Dent Res.1990;69 Spec No:601-5; discussion 634-6.

31. ten Cate JM, Duijsters PP. Influence of fluoride in solution on tooth demineralisation. II. Microradiographic data. Caries Res. 1983;17(6):513-9.

32. ten Cate JM, Featherstone JDB. Physicochemical aspects of fluoride-enamel interactions. In: Fejerskov O, Ekstrand J, Burt BA, editors. Fluoride in dentistry. 2nd ed. Copenhagen: Munksgaard; 1996. p. 252-72.

33. Brown WE, Gregory TM, Chow LC. Effects of fluoride on enamel solubility and cariostasis. Caries Res. 1977;11(Suppl 1):118-41.

34. Koulourides T. Increasing tooth resistance to caries through remineralisation. Foods Nutr Dent Health. 1982;2:193-207.

35. White DJ, Nancollas GH. Physical and chemical considerations of the role of firmly and loosely bound fluoride in caries prevention. J Dent Res. 1990;69 Spec No:587-94; discussion 634-6.

36. Gerould CH. Electron microscope study of the mechanism of fluorine deposition in teeth. J Dent Res. 1945;24:223-33.

37. Rošin-Grget K, Linčir I, Tudja M. Effect of amine fluoride on enamel surface morphology. Coll Antropol. 2000;24(2):501-8.

38. Christoffersen J, Christoffersen MR, Kibalczyc W, Perdok WG. Kinetics of dissolution and growth of calcium fluoride and effects of phosphate. Acta Odontol Scand. 1988;46(6):325-36. 
39. McCann HG. The solubility of fluorapatite and its relationship to that of calcium fluoride. Arch Oral Biol. 1968;13(8):987-1001.

40. Fejerskov O, Larsen MJ, Richards A, Baelum V. Dental tissue effects of fluoride. Adv Dent Res. 1994;8(1):15-31.

41. Øgaard B. $\mathrm{CaF}(2)$ formation: cariostatic properties and factors of enhancing the effect. Caries Res. 2001;35(Suppl 1):40-4.

42. Dijkman AG, De Boer P, Arends J. In vivo investigations on the fluoride content in and on human enamel after topical applications. Caries Res. 1983;17(5):392-402.

43. Caslavska V, Gron P, Kent RL, Joshipura K, DePaola PF. CaF2 in enamel biopsies 6 weeks and 18 months after fluoride treatment. Caries Res. 1991;25(1):21-6.

44. Rølla G, Saxegaard E. Critical evaluation of the composition and use of topical fluorides, with emphasis on the role of calcium fluoride in caries inhibition. J Dent Res. 1990;69 Spec No:780-5.

45. Øgaard B, Seppä L, Rølla G. Professional topical fluoride applications - clinical efficacy and mechanism of action. Adv Dent Res. 1994;8(8):190-201.

46. Saxegaard E, Rölla G. Fluoride acquisition on and in human enamel during topical application in vitro. Scand J Dent Res. 1988;96(6):523-35.

47. Rošin-Grget K, Linčir I, Andrijanić L. In vitro fluoride uptake by enamel from different amine fluoride concentrations. Caries Res. 2002;36:266-9.

48. Rošin-Grget K, Šutej I, Linčir I. The effect of saliva on the formation of $\mathrm{KOH}$-soluble fluoride af- ter topical application of amine fluoride solutions of varying fluoride concentration and $\mathrm{pH}$. Caries Res. 2007;41(3):235-8.

49. Larsen MJ, Richards A. The influence of saliva on the formation of calcium fluoride-like material on human dental enamel. Caries Res. 2001;35(1):57-60.

50. Hamilton IR, Bowden GHW. Fluoride effects on oral bacteria. In: Fejerskov O, Ekstrand J, Burt BA, editors. Fluoride in dentistry. 2nd ed. Copenhagen: Munksgaard; 1996. p. 230-51.

51. Koo H. Strategies to enhance the biological effects of fluoride on dental biofilms. Adv Dent Res. 2008;20(1):17-21.

52. Marquis RE. Antimicrobial actions of fluoride for oral bacteria. Can J Microbiol. 1995;41(11):955-64.

53. Hamilton IR. Biochemical effects of fluoride on oral bacteria. J Dent Res. 1990;69 Spec No: 660-7; discussion 682-3.

54. ten Cate JM, van Loveren C. Fluoride mechanisms. Dent Clin North Am. 1999;43(4):713-42.

55. Bowen WH. Caries prevention--fluoride: reaction paper. Adv Dent Res. 1991;5:46-9.

56. Van Loveren C. The antimicrobial action of fluoride and its role in caries inhibition. J Dent Res. 1990;69 Spec No:676-81; discussion 682-3.

57. Lynch RJ, Navada R, Walia R. Low-levels of fluoride in plaque and saliva and their effects on the demineralisation and remineralisation of enamel; role of fluoride toothpastes. Int Dent J. 2004;54(5 Suppl 1):304-9.

58. Marsh PD. Contemporary perspective on plaque control. Br Dent J. 2012;212:601-6. 